\title{
Superficial Lymph Node
}

National Cancer Institute

\section{Source}

National Cancer Institute. Superficial Lymph Node. NCI Thesaurus. Code C102716.

A lymph node located in a superficial part of the body. 